\title{
Influencing of Leadership Styles on Management of Teaching and Fostering Self-Directed Learning for Primary Schoolers at District 10 Ho Chi Minh City
}

\author{
Truong Phan Nguyen Dong (corresponding author) \\ University of Social Science and Humanities Vietnam National University Ho Chi Minh City \\ Tel: 84-937-960-567Ｅmail: truongphannguyen.ebkmf@gmail.com
}

Received: September 24, 2021 Accepted: October 26, 2021 Published: November 5, 2021

doi:10.5296/ijld.v11i4.19049 URL: https://doi.org/10.5296/ijld.v11i4.19049

\begin{abstract}
The research investigated the relationship between current management of fostering and developing self-directed learning and leadership styles of headmasters at primary schools at District 10 Ho Chi Minh City. The sample was applied with a formula by Waston (2001). According to Waston (2001), with a population varied from 700 to 800, and confident level of $95 \%$, and a variable of $50 \%$, the accepted sample should be varied from 255 to 267 . The total population of primary teachers at District 10, Ho Chi Minh City was 769 teachers, thus, the sample within this research was 265 teachers. The result indicated that transactional leadership impacted significantly to the management of fostering and developing self-directed learning at primary schools at District 10 Ho Chi Minh City. The result also indicated that headmasters should be flexible in applying leadership styles with different staffs.
\end{abstract}

Keywords: Leadership styles, management of fostering and developing self-directed learning for primary schoolers

\section{Introduction}

Resolution No. 29-NQ/TW, dated November 4, 2013, of Vietnam government in terms of the fundamental and comprehensive reform of education and training emphasized "improving the quality and effectiveness of research and applying science and technology, especially educational science and management science" to successfully conduct the fundamental and comprehensive renovation of the education system in the country. Within these aspects, the role and impact of educational leaders are one of the central reforms in this new direction. According to the research of Guskin, AE, \& Bassis, MA (1985), Dahncke, H. (1993), Engen 
et al. (2001), Schmid, H. (2006), Sole, F. (2009), all these authors suggested that leadership style has a huge impact on organizational performance. In the reform of education, teaching and learning activities, including the ability to self-directed learning, are one of the new development orientations of Vietnamese Education. This study aims to investigate the relationship between leadership styles and management of fostering and developing self-directed learning for primary school students in District 10, Ho Chi Minh City.

\section{a. Management concept}

Management is a field studied by many Vietnamese and foreign scholars and it has a long history of research. However, within the scope of research, the study would like to give the researchers' approach to management views and synthesize from there, it is proposed that the management perspective is used as a theory basis in this study. Based on theories and practices of management, researchers have given their views on management as a purposeful effect (Pham Minh Hac, 1986; Nguyen Quoc Chi and Nguyen Thi My Loc, 1997; Nguyen Ngoc Quang, 1997; Nguyen Minh Dao, 1997) of the management subject to the management object to achieve the common goals of the organization. Besides that, the researchers also added other points of view. According to H. Koontz (1992), he believed that management was an essential activity, it ensured the coordination of efforts of individuals to achieve organizational goals. The aim of every manager is to create an environment in which people can achieve their goals with the least amount of time, money, material, and personal dissatisfaction. Group of researchers including Nguyen Quoc Chi and Nguyen Thi My Loc (1997) said that: "Management activity is the directional and intentional impact of the management subject (manager) on the managed object (person managed) within an organization to enable it to function and achieve its goals". According to Dang Quoc Bao (2008), management is two parallel activities, coordinating and mobilizing to help the organization adapt and operate effectively in an interactive environment between the organization and external factors, between the organization and the organization's functions and internal factors. In this study, the author believed that management is an activity that always has two components, the subject of management and the object of management. The management subject can be an individual or a group of people who have the function of planning, organizing, pointing, and controlling so that the organization can operate effectively and achieve its goals. Management objects are those who are under the influence of the managed subject to achieve common goals.

\section{b. Self-directed learning of primary schoolers}

Self-directed learning is one of the topics attracting many Vietnamese scholars interested in research. Within the limits of our research, we have found some definitions of the self-directed learning of Vietnamese researchers. In which, Nguyen Canh Toan $(1997,2002)$ was the first to give a full perspective on self-directed learning in Vietnam. He believed that self-directed learning is brainstorming by yourself, using your own intellectual abilities (such as monitoring, comparing, analyzing, synthesizing, ...) and sometimes even muscle capacity (such as when to use tools, means, ...) along with their personal qualities such as motivation, affection, life view, worldview (such as honesty, objectivity, progress, ...) to dominate a 
certain field of human knowledge and make it his property. This view has been agreed and cited by many Vietnamese researchers such as: Nguyen Thi Lan Huong (2009); Duong Van Phuong (2011); Lam Thi Bach Tuyet (2013); Le Van Hai (2014). In addition, some other scholars also added their views on self-directed learning such as: self-directed learning is often understood self-directed learning as an individual cognitive activity (Tran Thi Dung, 2012); self-directed learning can be carried out outside the classroom and has a strong personal identity (Dang Vu Hoat, Ha Thi Duc, 2013); self-directed learning is the ability to perceive and apply knowledge to new situations (Dang Thanh Hung, 2000; Le Cong Triem, 2001).

Thus, from 1975 until now, Vietnamese scholars have inherited and made comments and added to the theory of self-directed learning quite fully and completely. When it comes to self-directed learning, scholars commented about individual needs, autonomy, cognitive autonomy, and individual responsibility in learning. Self-directed learning can take place in any space with different situations. Self-directed learning is applying knowledge to new situations. Besides, in Circular 32/2018/TT-BGDĐT of MOET Vietnam (2018) promulgating the new general education program, Hanoi, December 26, 2018, the Ministry of Education of Vietnam has a clear definition of self-directed learning in elementary school students. Students with self-directed learning consciously summarizing and presenting what they have learned. Students with self-directed learning can recognize and correct errors in the test through the teacher's comments. Students with self-directed learning consciously learn from teachers, friends, and others to consolidate and expand their understanding. Students have a sense of learning and follow good examples. Within the scope of this research, we use the definition of self-directed learning from the point of view of the Ministry of Education and Training, Vietnam. Thus, in this study, we follow the view of the Ministry of Education and Training on the concept of self-directed learning of primary school students.

\section{c. Teaching and fostering self-directed learning for primary schoolers}

Teaching and fostering competency for students is one of the topics in recent years attracting many scholars and researchers in Vietnam. According to Nguyen Cat Tuong Anh (2019), Anh stated that teaching and fostering competency for students in the process of organizing and implementing activities of teachers and students based on educational programs towards the formation and development of competency for students such as developing self-control and self-study, communication and cooperation, problem-solving through activities to form students' competencies such as language, computation, natural and social inquiry, technology, informatics, aesthetic, physical and gifted students. According to Le Dinh Trung and Phan Thi Thanh Hoi (2020), teaching and fostering competency is teaching-oriented to develop learners' capacity, which is a teaching activity that expands content-oriented by creating an environment, context, and teaching specific context for students to perform activities to apply knowledge, use skills, and express their attitudes. Within the scope of the topic and research, research applied the concept of teaching and fostering competency of Le Dinh Trung and Phan Thi Thanh Hoi (2020).

From the theory of teaching and fostering competency and self-directed learning of primary 
school students, self-directed learning training and fostering activities for primary school students are understood as content-oriented teaching activities, methods. The method of teaching aims to create a specific context for students to consciously summarize, present what they have learned, and be able to recognize and correct errors in the examination through the teacher's comments. self-directed learning students know how to learn from teachers, friends, and others to expand their understanding. In the view of Le Dinh Trung and Phan Thi Thanh Hoi (2020), the content of self-directed learning training and fostering activities for primary school students includes elements of teaching activities, such as teaching objectives, teaching content, teaching method, and testing methods and teaching equipment.

\section{d. Management of teaching and fostering self-directed learning for students' primary school}

The management of teaching activities to develop self-directed learning ability for primary school students is understood as the purposeful impact of the management subject on teaching and learning activities. Fostering self-directed learning for primary school students activities is conducted by teachers through the implementation of management functions in determining objectives, content, teaching methods and assessment, together with the use of teaching media and organization of learning activities for students. The purpose of the management of teaching activities to develop self-directed learning for elementary students is to help students consciously summarize and present what they have learned, be able to recognize and correct mistakes through the teacher's comments, to consciously learn from teachers, friends and others to strengthen and expand understanding, and to have a sense of learning and following good examples. The purpose of the management of teaching activities to develop self-directed learning for elementary students is to help students consciously summarize and present what they have learned, be able to recognize and correct mistakes. to fail the test through the teacher's comments, to consciously learn from teachers, friends and others to strengthen and expand understanding, and to have a sense of learning and following good examples.

On the basis of the theory of management activities and management of teaching activities to develop self-directed learning for primary school students, the content of teaching management activities to develop self-directed learning for elementary students is determined. The decision includes the following issues: Management of teaching activities to develop self-study capacity (including: management of teaching objectives to develop self-directed learning, management of teaching content to develop self-directed learning, management of manage teaching forms to develop self-directed learning, manage teaching methods to develop self-directed learning, manage examination and evaluation activities); Managing students' learning activities in order to develop self-directed learning; Managing teaching means to develop students' self-directed learning.

\section{e. Leadership style impacts on the management of training activities to develop self-directed learning in elementary school students}

Dahncke, H. (1993) carried out through experimental activities in an educational institution in 1989 while Engen et al (2001) studied of the influence of factors such as gender, leadership 
styles on organizational performance. Besides that, Guskin, A. E., \& Bassis, M. A. (1985) argued that leadership style is influenced by the control and authority of the leader. Schmid, H. (2006) argued that leaders have an impact on the organization through their vision, values, code of behavior and leadership styles. On the other hand, Sole, F. (2009) argued that leadership style plays an important role in influencing employees' commitment to achieving working goals as well as employee performance through design and performance activities and develop effective measurement systems.

According to Burn (1978), he argued that leadership was described as motivating followers to pursue common or at least common goals that represent the values and motivations of both leaders and followers. Burn (1978) also classified leadership into two groups as transformational leadership and transactional leadership. Transformational leadership involves an exchange of benefits and is based on the current values and motivations of both leaders and employees. On the other hand, transactional leadership does not consider existing values and dynamics to be fixed, but rather seeks to change them. In view of Burn (1978) and Bass (1985) found that transactional leadership consists of two elements - incidental reward and exceptional management, and transformational leadership consists of three elements. factors - charisma, encouragement and personal consideration. Besides, Bass (1985) also added one of leadership style, laissez-faire.

According to Bass (1985), the three leadership styles including: transactional leadership; transformational leadership and laissez-faire leadership.

- The transactional leadership, according to Bass (1985), focuses on supervision, organization and performance. The transactional leadership style was build a clear framework, so that subordinates know what they are asked to do and the corresponding rewards for doing it well. Punishment is often not described in detail, but the participants in this leadership system are well understood and this reward-punishment system is always strictly maintained. With the exception of the transactional leadership style, the leader uses negative feedback when subordinates do not meet expectations.

- Transformational leadership, according to Bass (1985), includes charisma, intellectual stimulation, and personal consideration. Transformational leadership styles represent idealized influence. According to Silins (1992), when explaining the elements of transformational leadership style, he considers charisma to be a leader's ability to generate enthusiasm in subordinates and inspire loyalty and devotion. In addition, Silins (1992) suggested that intellectual stimulation is a leader's ability to inspire subordinates to think in innovative ways, to make subordinates aware of problems and think about problems. possible solutions. Silins (1992) also suggested that personal consideration by paying attention to the specific needs and skills of subordinates and adapting to their individual differences as part of day-to-day management work. their. They support subordinates in their personal development through some form of coaching.

- Empowerment leadership style/ laissez-faire, according to Bass (1985), the empowering leadership style often refuses to take responsibility for decision-making, avoids conflict, and is often absent when subordinates need them. According to Bass (1985), empowering 
leadership style gives all authority to employees, giving employees autonomy. According to Bass (1985), leaders in this style need to have standards in company rules or company charters to keep the balance and stability of the organizational apparatus.

\section{Research Method and Sample}

\subsection{Sample}

According to Watson (2001), with the total population varying from 700 to 800 people, with a confidence level of 50\%, the appropriate sample size ranges from 255 to 267 people. The total number of primary school teachers in District 10, Ho Chi Minh City was 769 people, so, the survey sample in this thesis is 265 people, according to the formula of Watson (2001) is appropriate. The survey sample included 265 primary school teachers, of which 94 male teachers $(35.5 \%)$ and 171 female teachers (64.5\%). By seniority, there were 74 primary school teachers with less than 5 years of experience (accounting for 27.9\%); there were 79 primary school teachers with 6 to 10 years of working experience (accounting for 29.8\%); There were 55 primary school teachers with 11 to 15 years of experience (accounting for $20.8 \%$ ); There were 36 primary school teachers with 16 to 20 years of experience (accounting for $13.6 \%$ ); There were 21 primary school teachers with more than 20 years of experience (accounting for $7.9 \%$ ).

\subsection{Research Method}

The main research method in this study was the questionnaire survey method. Based on the theoretical basis, the researchers built a questionnaire with contents about the actual situation of self-directed learning training activities. The author used a 5-level Likert or nominal scale with the number of observed variables depending on the content of the question group. The author used a 5-level Likert scale and divides the levels according to the following formula: the values of the items, level $=(5-1) / 5=0.8$ (followed by Duong Minh Quang et al., 2018). Therefore, the significance of the levels is divided as follows: Average score from 1.00 to 1.80: completely dissatisfied / completely disagree / completely unimportant; Average score from 1.81 to 2.60: not satisfied/disagree/not important; Average score from 2.61 to 3.40: partly satisfied / partly agree / partly important; Average score from 3.41 to 4.20: satisfied/agree/important; Average score from 4.21 to 5.00: completely satisfied/strongly agree/strongly important.

After having the content of the questionnaire, the study invited 35 teachers from primary schools voluntarily test the questionnaire (these teachers will not be invited to participate in the official survey). The purpose of the pilot survey was for the teachers to give feedback on the language used and to check if the teachers' time is appropriate so that appropriate adjustments can be made before conducting a formal investigation. The reliability and validity of the scale were tested using Cronbach's Alpha reliability coefficient method and exploratory factor analysis (EFA) through SPSS 20.0 processing software to screen, remove observed variables that do not meet the reliability criteria.

Inheriting the theoretical framework by Bass (1985), Dussault et al (2013) built a scale of leadership style with 21 items and three leadership styles: Transactional Leadership; 


\section{Macrothink Institute ${ }^{\mathrm{TM}}$}

transformation style; Empowerment leadership style/ laissez-faire. In which, transformational leadership style has 3 sub-factors: Charisma (4 items), Individual Consideration (4 items), and Intellectual Stimulation (4 items); The transitional leadership style has two sub-factors: Contingent reward ( 3 items) and management by exception (3 items). Empowerment leadership style/ laissez-faire has no extra elements but includes 3 items. Cronbach Alph index according to study by Eric et al (2003) is 0.92 for Charisma factor, 0.97 for Intellectual Stimulation factor; 0.98 for Individual Consideration; 0.96 for the Contingent reward factor; 0.99 for management by exception and 0.98 for Empowerment leadership style/ laissez-faire style scale.

\section{Results}

\subsection{Cronbach's Alpha and Exploratory Factors Analysis}

The results of testing the reliability of Cronbach's alpha and the exploratory factor analysis to examine the scale of teaching and learning management activities to develop self-directed learning and the leadership style scale were presented in Table 01. The test results indicated that the scale has full reliability (Cronbach's alpha coefficient varies from 0.898 to 0.937 with the scale of teaching and learning management activities to develop self-directed learning and Cronbach's alpha coefficient varies from 0.61 to 0.80 ). The scale of management of teaching and learning activities to develop self-directed learning extracted 7 factors with factor loading coefficient varying from 0.503 to 0.862 (KMO value reached 0.921 ). The leadership style scale extracted 6 factors with the factor loading coefficient varying from 0.749 to 0.887 (KMO value reached 0.8399).

Table 1. Results of Cronbach's alpha and Exploratory factors analysis of Management of teaching and fostering self-directed learning scale and leadership style scale

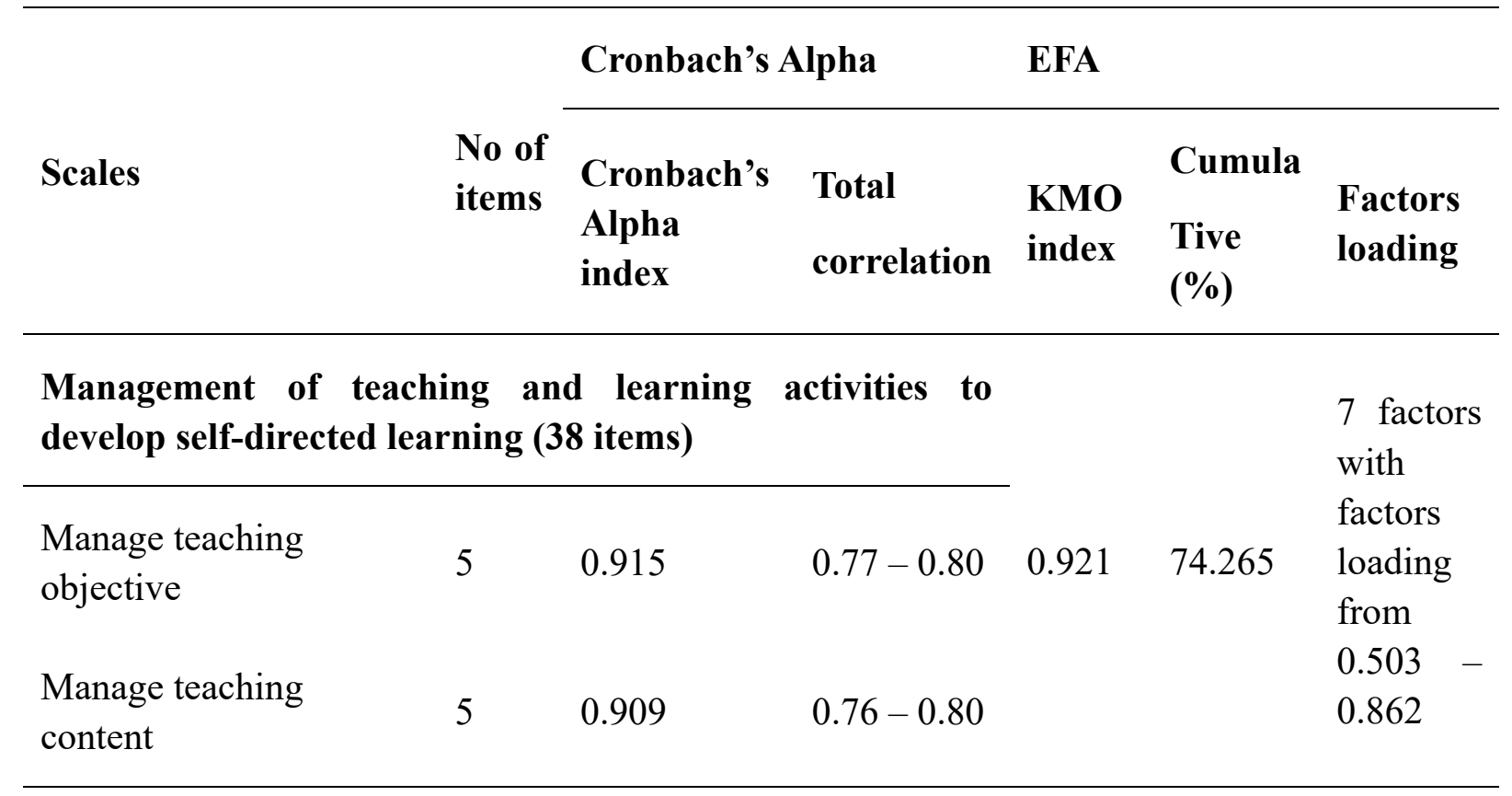


Manage teaching method
5
0.898
$0.73-0.80$

Manage teaching organizing
5
0.905
$0.72-0.79$

Manage evaluating

$5 \quad 0.904$

$0.72-0.80$

Manage learning activities

8

0.931

$0.68-0.85$

Manage teaching euquipments

$5 \quad 0.937$

$0.73-0.86$

Leadership style scale (21 items)

Transformation leadership style (12 items)

\begin{tabular}{|c|c|c|c|c|c|c|c|}
\hline & Charisma & 4 & 0.860 & $0.61-0.78$ & \multirow{7}{*}{0.8399} & \multirow{7}{*}{76.767} & \multirow{7}{*}{$\begin{array}{l}6 \text { factors } \\
\text { with } \\
\text { factor } \\
\text { loading } \\
\text { from } \\
0.749 \quad- \\
0.887\end{array}$} \\
\hline & $\begin{array}{l}\text { Individual } \\
\text { Consideration }\end{array}$ & 4 & 0.890 & $0.75-0.80$ & & & \\
\hline & $\begin{array}{l}\text { Intellectual } \\
\text { Stimulation }\end{array}$ & 4 & 0.91 & $0.74=0.87$ & & & \\
\hline \multicolumn{5}{|c|}{ Transactional leadership style (6 items) } & & & \\
\hline & $\begin{array}{l}\text { Contingent } \\
\text { reward }\end{array}$ & 3 & 0.880 & $0.77-0.77$ & & & \\
\hline & $\begin{array}{l}\text { Management by } \\
\text { exception }\end{array}$ & 3 & 0.805 & $0.63-0.73$ & & & \\
\hline Laiss & ez-faire style (3 iter & & 0.830 & $0.63-0.72$ & & & \\
\hline
\end{tabular}

3.2 The Management of Teaching Activities to Develop Self-Directed Learning for Primary School Students in District 10 Ho Chi Minh City

According to the research results, the content of evaluation management is considered by primary school teachers to be the most effective (mean score of 4.29, standard deviation of 0.54). In addition, the research results also revealed that the content of the management of 


\section{Macrothink}

International Journal of Learning and Development

ISSN 2164-4063

2021, Vol. 11, No. 4

learning activities and the management of teaching equipments were highly rated effective by primary school teachers (mean score: $4.20 ; 4.21$; standard deviation: $0.59,0.63$ ). The content of management work to develop teaching goals is rated to be less effective than other management contents (mean score is 4.07 and standard deviation 0.72). Independent $T$ - Test tests the difference in the evaluation of the effectiveness of the contents of management and between teachers. The results of the Independent T-test showed that the teachers were quite similar in terms of the effectiveness of the management content, but in the content of teaching media management, there was a significant difference. Statistical significance between male teachers and female teachers in term of evaluating effectiveness of Management of teaching and learning activities to develop self-directed learning. Specifically, the teachers rated the content of the management of teaching euipment higher than the teachers' evaluations (average score of $4.34>4.13$ ).

Table 2. Management of teaching and learning activities to develop self-directed learning of primay schools in District 10 Ho Chi Minh City

\begin{tabular}{lllll}
\hline $\begin{array}{l}\text { Management of teaching and } \\
\text { learning activities to develop } \\
\text { self-directed learning }\end{array}$ & Male & Female & Sum & F \\
\hline Manage teaching objective & $3.99(0.86)$ & $4.12(0.63)$ & $4.07(0.72)$ & -1.337 \\
Manage teaching content & $4.11(071)$ & $4.18(0.66)$ & $4.15(0.68)$ & -0.791 \\
Manage teaching method & $4.10(0.74)$ & $4.10(0.66)$ & $4.10(0.69)$ & -0.07 \\
Manage teaching organizing & $4.05(0.71)$ & $4.16(0.65)$ & $4.13 \quad(0.68)$ & 0.200 \\
Manage evaluating & $4.30(0.59)$ & $4.28(0.52)$ & $4.29(0.54)$ & 0.215 \\
Manage learning activities & $4.28(0.62)$ & $4.16(0.57)$ & $4.20(0.59)$ & 1.689 \\
\hline Manage teaching euquipments & $4.34(0.60)$ & $4.13(0.64)$ & $4.21(0.63)$ & $2.503 * * *$ \\
\hline
\end{tabular}

Note. ${ }^{* * *}$ when $p<0.01$ 
3.3 The Leadership Styles of Headmasters of Primay Schools in District 10 Ho Chi Minh City

Table 3. Leadership styles of primary schools' headmasters at District 10 Ho Chi Minh City

\begin{tabular}{lllll}
\hline \multirow{2}{*}{ Leadership styles scale } & \multicolumn{1}{l}{ Male teachers } & Female teachers & Sum \\
\cline { 2 - 4 } & Mean (Std.D) & Mean (Std.D) & \multicolumn{2}{c}{ Mean (Std.D) } \\
\hline $\begin{array}{l}\text { Transformational } \\
\text { style }\end{array}$ & $3.89(0.49)$ & $3.97(0.53)$ & $3.94(0.52)$ & 1.333 \\
Transactional leadership style & $3.72(0.62)$ & $3.79(0.63)$ & $3.76(0.62)$ & 0.879 \\
Laissez-faire leadership style & $1.90(0.92)$ & $2.23(1.1)$ & $2.19(1.01)$ & 10.339 \\
\hline
\end{tabular}

According to the results of leadership styles, the dominant leadership style amongst headmasters of primary schools in District 10, Ho Chi Minh City, according to rating of teachers, was transformational style (Mean=3.94 and $\mathrm{SD}=0.52$ ). Most of headmasters was believed by teachers that he or she was belong to transformational leadership style including showing his/her charisma; focusing on individual consideration and intellectual stimulation. Whereas, laissez-faire leadership style was not considered by teachers as main headmasters' leadership styles. Besides that, the result also revealed that there was no difference between male and female teachers in evaluating and rating leadership styles of headmasters.

\subsection{Leadership Styles Affects the Management of Teaching and Fostering Self-Directed Learning for Primary Schoolers in District 10 Ho Chi Minh City.}

The results of correlation and regression analysis between the headmasters' leadership styles and the management of teaching and fostering self-directed learning for elementary school students in District 10, Ho Chi Minh City indicated that all three styles have strong correlation with the management of teaching and fostering self-directed learning for students at primary schools in District 10, Ho Chi Minh City (correlation coefficient varies from 0.342 to 0.451 , significance level $<0.01$ ). In particular, the strongest correlation was between transformational leadership style and management of teaching and fostering self-directed learning for primary schoolers in District 10 Ho Chi Minh City (Pearson coefficient $=0.451$; significance level $\mathrm{p}<0.01$ ). The weakest correlation was between the laissez-faire leadership style and the management of teaching and fostering self-directed learning for primary school students in District 10 Ho Chi Minh City (Pearson coefficient $=0.342$, significance level $\mathrm{p}<0.01)$. In addition, the transformational leadership has the strongest influence, accounting for changing $20.1 \%$ of the management of teaching and fostering self-directed learning for primary school students in District 10 Ho Chi Minh City. Laissez-faire leadership style has the weakest impact on change, accounting for only $11.4 \%$ of the management of teaching and fostering self-directed learning for primary school students in District 10 Ho Chi Minh. 
Table 4. Correlation and single regression between leadership style and management of teaching and fostering self-directed learning for primary school students in District 10 Ho Chi Minh City

\begin{tabular}{|c|c|c|}
\hline \multirow{2}{*}{ Impacting variables } & \multicolumn{2}{|c|}{$\begin{array}{l}\text { Management of teaching and fostering self-directed } \\
\text { learning for primary school students in District } 10 \mathrm{Ho} \text { Chi } \\
\text { Minh City }\end{array}$} \\
\hline & $\begin{array}{l}\text { Pearson correlation } \\
\text { index }\end{array}$ & Single regression index $r^{2}$ \\
\hline Transformational leadership & $0.451 * *$ & $0.201 * * *$ \\
\hline Transactional leadership & $0.398 * *$ & $0.156^{* * *}$ \\
\hline Laissez-faire leadership style & $0.342 * *$ & $0.114 * * *$ \\
\hline
\end{tabular}

Note. ** when $p<0.01$; *** when $p<0.001$.

However, in reality, leaders cannot use only one leadership style for all his objectives. Therefore, the multiple regression analysis was administrated to detect the optimal and more realistic regression models. The results of multiple regression analysis indicated that there were 3 optimal predictive models, of which model 01 (only transformational leadership style) explains at least the change in the management of teaching and fostering self-directed learning for primary school students in District 10 Ho Chi Minh City, explained 20.1\%. Model 03 (combination of transformational leadership style, Laissez-faire leadership style and Transactional leadership style) explained the most changes in the management of teaching and fostering self-directed learning for primary school students in District 10 Ho Chi Minh City, accounting for $32 \%$ of the changes. From the results of the above multiple regression analysis, it is possible to format an equations to predict the changes in the management of teaching and fostering self-directed learning for primary school students in District 10 Ho Chi Minh City by leadership styles. With model number 03, we have the following equation: Changes in the management of teaching and fostering self-directed learning for primary school students in District 10 Ho Chi Minh City $=2.904$ (constant) +0.34 (transformational leadership style) +0.259 (Laissez-faire leadership style) +0.213 (transactional leadership style). In this model, transformational leadership style was the most influential variable $(\mathrm{Beta}=0.341)$ and transactional leadership style is the weakest influencing variable $(\mathrm{Beta}=0.213)$. 
Table 5. The model predicts the influence of the headmasters' leadership styles on the management of teaching and fostering self-directed learning for primary school students in District 10 Ho Chi Minh City

\begin{tabular}{|l|l|l|l|}
\hline $\begin{array}{l}\text { Three models predicting the influence of leadership styles } \\
\text { on the management of teaching and fostering self-directed } \\
\text { learning for primary school students in District 10 Ho Chi } \\
\text { Minh City }\end{array}$ & Beta & $\begin{array}{l}\text { Meaningful } \\
\text { level p }\end{array}$ \\
\hline \multicolumn{2}{|l|}{ Model 01: $r^{2}=0.201 ;$ constant $=2.549 ; p<0.001$} & 0.451 & 0.000 \\
\hline 1 & Transformational leadership style & 0.418 & 0.000 \\
\hline Model 02: $r^{2}=0.285 ;$ constant $=2.388 ; p<0.001$ & 0.296 & 0.000 \\
\hline 1 & Transformational leadership style & 0.213 & 0.000 \\
\hline 2 & Laissez-faire leadership style & 0.341 & 0.000 \\
\hline Model 03: $r^{2}=0.320 ;$ constant $=2.094 ; p<0.001$ & 0.000 \\
\hline 1 & Transformational leadership style & 0.259 & \\
\hline 2 & Laissez-faire leadership style & Transactional leadership style & \\
\hline 3 & & & \\
\hline
\end{tabular}

Note. Dependent variable: the management of teaching and fostering self-directed learning for primary school students in District 10 Ho Chi Minh City

\section{Inpacting variable:Leadership style}

Model 01: Transformational leadership style

Model 02: Transformational leadership style, Laissez-faire leadership style.

Model 03: Transformational leadership style, Laissez-faire leadership style, Transactional leadership style.

\section{Discussion}

From the research results, it is shown that the management of teaching and fostering self-directed learning for primary school students in District 10 Ho Chi Minh City has been highly evaluated by teachers. In which, there was no difference between male and female teachers' evaluation of this management, except for the evaluation of teaching media management, which is more appreciated by teachers. The research results showed that the 
model that combines different leadership styles (Transactional leadership style, Laissez-faire leadership style, Transformational leadership style) strongly influences the management of teaching and fostering self-directed learning for primary school students in District 10 Ho Chi Minh City. In fact, leaders also need to be flexible in different leadership styles to create the best in operational management, which in this case is school operations management.

\section{Conclusion}

The research indicated that headmasters of primary schools at District 10, Ho Chi Minh City need to be flexible in leadership styles in management activities. However, there are several limitation of this research needed to be carried on in further researches. Firstly, the research results cannot be told which perpertives of teaching and fostering activities could be impacted by leadership styles. Secondly, commitment of teaching staffs has not mentioned yet in this research in term of influencing of headmasters' leadership styles.

\section{References}

Bass, B. M. (1985). Leadership and performance beyond expectations. New York: Free Press. Burns, J. M. (1978). Leadership. New York: Harper \& Row.

Dahncke, H. (1993). Leardership styles in teacher education and industry. International Journal of Technology and Design Education, 3(1), $21 \quad-39$. https://doi.org/10.1007/BF00418994

Đặng Quốc Bảo (2008). Tổng quan về Tổ chức và Quản lý, tài liệu dành cho các lớp Cao học Quản lý Giáo dục, 2008.

Đặng Thành Hưng (lược dịch) (2000). Một số vấn đề về phương pháp dạy học, Viện Khoa học Giáo dục, Hà Nội.

Đặng Vũ Hoạt (chủ biên). Hà Thị Đức (2013), Lí luận dạy học đại học, Nxb Đại học Sư phạm, Hà Nội.

Đỗ Thị Thùy (2019). Thực trạng và biện pháp ứng dụng công nghệ thông tin trong dạy học ở các trường Tiểu Học Quận Gò Vấp, Thành Phố Hồ Chí Minh, Tạp chí Giáo dục, Số đặc biệt tháng 7/2019, tr 21-24; 20

Dương Minh Quang, Nguyễn Thị Hảo, Nguyễn Hồng Phan. (2018). Hiệu quả giảng dạy của giảng viên lý luận và thực tiễn, Nhà xuất bản Đại học Quốc Gia Thành phố Hồ Chí Minh.

Dương Văn Phương (2011), Luận văn Thạc sỹ Quản lý Một Số Giải Pháp Quản Lý Hoạt Động Tự Học Của Học Sinh Trường Trung Học Phổ Thông Dân Tộc Nội Trú Tỉnh Thanh Hoá.Trường Đại học Vinh.

Dussault, M., Frenette, É., \& Fernet, C. (2013). Leadership: Validation of a Self-Report Scale. Psychological Reports, 112(2), 419-436. https://doi.org/10.2466/01.08.PR0.112.2.419-436

Engen, M. L., Leeden, R., \& Willemsen, T. M. (2001), Gender, context and leadership styles: A field study. Journal of Occupational and Organizational Psychology, 74(5), 581-598. 
https://doi.org/10.1348/096317901167532

Guskin, A. E., \& Bassis, M. A. (1985), Leadership styles and institutional renewal. New Directions for Higher Education, 1985(49), 13-22. https://doi.org/10.1002/he.36919854904

Hà Thị Dung. (2013). Quản Lý Hoạt Động Tự Học Của Học Sinh Trường Trung Học Cơ Sở Mông Ân Huyện Bình Gia - Lạng Sơn, Luận văn Thạc Sĩ với đề tài thuộc Đại Học Quốc Gia Hà Nội Trường Đại Học Giáo Dục.

Harold Koontz, Cyrill O,donnell. Heninz Weihrich. (1992). Những vấn đề cốt yếu của quản lý. Nhà xuất bản Khoa học Kỹ thuật, Hà Nội.

Hoàng Đức Trí. (2019)., Một số biện pháp tăng cường quản lí hoạt động ứng dụng công nghệ thông tin trong dạy học ở các trường trung học cơ sở Thành Phố Đông Hà, tỉnh Quảng Trị, Tạp chí Giáo dục, Số 444 (Kì $2 \quad-\quad 12 / 2018)$, $\operatorname{tr} \quad 9-13 ; 8$. https://doi.org/10.52714/dthu.39.8.2019.710

Lâm Thị Bạch Tuyết. (2013). Luận văn Thạc sỹ Biện Pháp Quản Lý Hoạt Động Tự Học Của Học sinh Khoa Sư Phạm Trường Đại Học Trà Vinh Trong Giai Đoạn Hiện Nay. Trường Đại học Đà Nẵng.

Lê Công Triêm. (2001). Bồi dưỡng năng lực tự học, tự nghiên cứu cho sinh viên đại học, Tạp chí giáo dục, số $8, \operatorname{tr} 30$ - 35 .

Lê Công Triêm. (2001). Một số vấn đề hiện nay của phương pháp dạy học hiện đại, Nxb Đại học Sư phạm, Hà Nội.

Lê Đình Trung, Phan Thị Thanh Hội. (2020). Dạy học theo định hướng hình thành và phát triển năng lực người học ở trường Phổ Thông, Nhà xuất bản Đại học Sư Phạm, Hà Nội.

Lê Văn Hải. (2014). Luận văn Thạc sỹ Quản Lý Hoạt Động Tự Học Của Học sinh Trường Đại Học Thủ Dầu Một, Tỉnh Bình Dương.

Ministry of Education and Training Vietnam (MOET Vietnam). (2018). General education program. Circular No. 32/2018/TT-BGDDT, dated December 26, 2018.

Nguyễn Cảnh Toàn (chủ biên), Nguyễn Kỳ, Lê Khánh Bằng, Vũ Văn Tảo. (2002). Học và dạy cách học, NXB Đại học Sư phạm.

Nguyễn Cảnh Toàn (chủ biên), Nguyễn Kỳ, Vũ Văn Táo, Bùi Tường. (1997). Quá trình dạy tự học, NXB Giáo dục, Hà Nội.

Nguyễn Cát Tường Anh. (2019). Quản lí hoạt động dạy học theo định hướng phát triển năng lực học sinh ở các trường trung học cơ sở công lập Quận Phú Nhuận Thành Phố Hồ Chí Minh, Luận văn Thạc sĩ Quản lý Giáo dục, Trường Đại học Sư Phạm Thành phố Hồ Chí Minh, 2019.

Nguyễn Minh Đạo (1997). Cơ sở khoa học quản lý, Nhà xuất bản chính trị quốc gia Hà Nội, 1997. 


\section{Macrothink}

International Journal of Learning and Development

ISSN 2164-4063

2021, Vol. 11, No. 4

Nguyễn Ngọc Quang. (1986). Lý luận dạy học đại cương. Trường Cán bộ quản lý Giáo dục.

Nguyễn Quang Thuận. (2019). Một số nguyên tắc ứng dụng công nghệ thông tin trong dạy học môn giáo dục công dân theo định hướng phát triển năng lực ở trường trung học phổ thông hiện nay, Tạp chí Giáo dục, Số 452 (Kì 2 - 4/2019), tr 61-64; bìa 3. https://doi.org/10.18173/2354-1075.2019-0008

Nguyễn Quốc Chí, Nguyễn Thị Mỹ Lộc. (1997). Những cơ sở khoa học về quản lý giáo dục, Trường cán bộ quản lý giáo dục, 1997.

Nguyễn Thị Lan Hương. (2009). Luận văn Thạc sĩ về Quản Lý Hoạt Động Tự Học Của Học sinh Khoa Ngôn Ngữ Và Văn Hóa Nga Trường Đại Học Ngoại Ngữ - Đại Học Quốc Gia Hà Nội Đáp Ú́ng Yêu Cầu Đào Tạo Theo Học Chế Tín Chỉ. Trường Đại học Giáo dục.

Phạm Minh Hạc. (1986). Một số vấn đề giáo dục và khoa học giáo dục. Nhà xuất bản Giáo dục. Hà Nội.

Resolution No. 29-NQ/TW dated November 4, 2013 of the 8th Central Conference of the XI term on fundamental and comprehensive reform of education and training.

Schmid, H. (2006). Leadership styles and leadership change in human and community service organizations. Nonprofit Management and Leadership, 17(2), 179-194. https://doi.org/10.1002/nml.142

Silins, H. C. (1992) Effective leadership for school reform. The Alberta Journal of Educational Research, 38, 317-334.

Sole, F. (2009). A management model and factors driving performance in public organizations. Measuring Business $\quad$ Excellence, https://doi.org/10.1108/13683040911006747

Trần Thị Dung. (2012). Nâng cao năng lực tự học cho sinh viên trong giảng dạy môn những nguyên lý cơ bản của chủ nghĩa mác - lênin (phần ii), Trường Đại học Vinh, 2012.

Watson, J. (2001). How to Determine a Sample Size: Tipsheet \#60, University Park, PA: Penn State Cooperative Extension.

\section{Copyright Disclaimer}

Copyright for this article is retained by the author(s), with first publication rights granted to the journal.

This is an open-access article distributed under the terms and conditions of the Creative Commons Attribution license (http://creativecommons.org/licenses/by/4.0/). 